\title{
Geotechnical and hydrological characterization of hillslope deposits for regional landslide prediction modeling
}

\author{
G. Bicocchi ${ }^{1}$ D $\cdot$ V. Tofani ${ }^{1} \cdot$ M. D'Ambrosio ${ }^{2} \cdot$ C. Tacconi-Stefanelli ${ }^{1} \cdot$ P. Vannocci $^{1} \cdot$ N. Casagli $^{1} \cdot$ G. Lavorini $^{3}$. \\ M. Trevisani $^{3} \cdot$ F. Catani $^{1}$
}

Received: 16 July 2018 / Accepted: 17 December 2018 / Published online: 24 January 2019

(C) The Author(s) 2019

\begin{abstract}
We attempt a characterization of the geotechnical and hydrological properties of hillslope deposits, with the final aim of providing reliable data to distributed catchment-scale numerical models for shallow landslide initiation. The analysis is based on a dataset built up by means of both field tests and laboratory experiments over 100 sites across Tuscany (Italy). The first specific goal is to determine the ranges of variation of the geotechnical and hydrological parameters that control shallow landslide-triggering mechanisms for the main soil classes. The parameters determined in the deposits are: grain size distribution, Atterberg limits, porosity, unit weight, in situ saturated hydraulic conductivity and shear strength parameters. In addition, mineral phases recognition via X-ray powder diffraction has been performed on the different soil types. The deposits mainly consist of well-sorted silty sands with low plastic behavior and extremely variable gravel and clay contents. Statistical analyses carried on these geotechnical and hydrological parameters highlighted that it is not possible to define a typical range of values only with relation to the main mapped lithologies, because soil characteristics are not simply dependent on the bedrock type from which the deposits originated. A second goal is to explore the relationship between soil type (in terms of grain size distribution) and selected morphometric parameters (slope angle, profile curvature, planar curvature and peak distance). The results show that the highest correlation between soil grain size classes and morphometric attributes is with slope curvature, both profile and planar.
\end{abstract}

Keywords Soil geotechnics $\cdot$ Morphometric analysis $\cdot$ Physically based modeling $\cdot$ Shallow landslides $\cdot$ Tuscany

\section{Introduction}

The use of physically-based landslide prediction models for rainfall-triggered shallow landslides has recently increased because reliable landslide hazard maps with time prediction capability are needed to reduce damage and human losses

Electronic supplementary material The online version of this article (https://doi.org/10.1007/s10064-018-01449-z) contains supplementary material, which is available to authorized users.

G. Bicocchi

gabriele.bicocchi@unifi.it

1 Department of Earth Sciences, University of Florence, Via La Pira 4, 50121 Firenze, Italy

2 INGV (National Institute of Geophysics and Volcanology), via della Faggiola 32, 56126 Pisa, Italy

3 Regione Toscana, Direzione Urbanistica e Politiche Abitative, Sistema Informativo Territoriale ed Ambientale, Via di Novoli 26, 50127 Firenze, Italy
(Fanelli et al. 2016), and many models have been presented in the literature (Pack et al. 2001; Baum et al. 2002; Rosso et al. 2006; Simoni et al. 2008; Baum et al. 2010; Ren et al. 2010; Arnone et al. 2011; Salciarini et al. 2012; Mercogliano et al. 2013; Rossi et al. 2013; Reid et al. 2015; Alvioli and Baum 2016; Salciarini et al. 2017).

One of the crucial factors that controls the accuracy of the physically-based model predictions is the availability of detailed databases of physical and mechanical properties of rocks and soils in the selected study areas (e.g., Oreskes et al. 1994). Furthermore, the poor comprehension of the spatial organization of the geotechnical and hydrological input parameters interferes with the application of models over large areas (e.g., Iwashita et al. 2012; Tofani et al. 2017; Salvatici et al. 2018). The performance of a model can be strongly influenced by the errors or uncertainties in such input data (Segoni et al. 2012; Jiang et al. 2013; Nikolopoulos et al. 2014; Marra et al. 2017; Peres et al. 2018). Geotechnical and hydrological variables are difficult to manage and their measurement is difficult, time-consuming and expensive, 
especially when working on large, geologically complex areas (Carrara et al. 2008; Godt et al. 2008; Baroni et al. 2010; Park et al. 2013; Bicocchi et al. 2015; Tofani et al. 2017). Indeed, as is well known in geotechnical engineering studies that deal with slope stability (e.g., Phoon and Kulhawy 1999; Akbas and Kulhawy 2010), soil properties are characterized by neither uniform nor continuous spatial distributions, with an high total variability (both vertical and horizontal). That variability includes the actual soil variability (inherent variability) and other uncertainties (e.g., measurement and sampling errors). Despite this, several natural features prove to have a spatial autocorrelation (e.g., Catani et al. 2013) dependent on the observation scale that is at the base of geostatistical methods (e.g., kriging). For this reason, it is common to assign a unique value to what is being studied according to the scale. Average values of soil parameters consider the variability in the areas, leading to their trend and their spatial behavior. Therefore, they can be fundamental in physically-based models at catchment or regional scale to assess the general risk of shallow landslides. Then, where needed, a more in-depth analysis could to be performed using real local parameters for confirmation.

In order to prepare the input data and feed the physicallybased models different approaches can be used: (1) the adoption, for each parameter, of a unique constant value for the whole study area as averaged from in situ measurements or derived from literature data (e.g., Jia et al. 2012; Peres and Cancelliere 2014), (2) the adoption of a set of constant values of the parameters for distinct geological, lithological or lithotecnical units, as derived from direct measurements (Segoni et al. 2009; Baum et al. 2010; Montrasio et al. 2011; Zizioli et al. 2013; Bicocchi et al. 2016) or from existing databases and published data (Lepore et al. 2013; Ren et al. 2014; Tao and Barros 2014), or (3) the definition of cohesion and friction angle values as random variables using a probabilistic or stochastic approach (e.g., Griffiths et al. 2011; Park et al. 2013; Chen and Zhang 2014; Raia et al. 2014; Fanelli et al. 2016; Salciarini et al. 2017). The latter does not consider any physical process in the spatial distribution of the parameters while the second one assumes that their distribution is related to lithology of the bedrock or to other morphometric parameters.

In some countries, such as in the U.S.A. by the NRCS (Natural Resource Conservation Service), soil maps with many of the relevant parameters modeling shallow landslide initiation are already available. Instead, in Italy, complete, systematically structured and organized geo-databases that characterize different soil types at large scales providing information on their spatial distribution are still lacking. To contribute to filling this gap, this work seeks to create a database of hydrological and geotechnical parameters for physicallybased landslide prediction models, characterizing with especial regard the materials involved in shallow landsliding.
The study area is the entire Tuscan region, located in central Italy, which is heavily affected by landslides (over 90,000, according to the inventory of the Tuscan regional authority updated by using remote sensing techniques; Rosi et al. 2017). In Tuscany, surficial hillside materials (i.e., upper $\sim 2 \mathrm{~m}$ ) are typically comprised of unconsolidated, geologically recent, mostly granular materials and soils, and are frequently affected by shallow landslides, i.e., translational slides, soil slips, and debris flows (D'Amato Avanzi et al. 2004). Such deposits are generally described as "colluvium" (Goudie 2003), and may originate from different sources and processes, depending on the physical agents and/or the chemical processes that have acted on them, breaking up and altering the bedrock.

The main scope of the work is to create a homogenous set of data concerning the principal geotechnical and hydrological properties of the materials constituting the deposits by means of an extensive campaign of in situ and laboratory measurements, with the final aim of providing reliable input data to physically-based landslide prediction models, at a catchment scale, for shallow landslide initiation. Toward this purpose, the specific objectives to be achieved are: (1) to determine the ranges of variation of the geotechnical and hydrogeological parameters that control shallow landslide triggering mechanisms, and (2) to investigate a way to spatially describe the variation in the geotechnical and hydrological data according to the information contained in the geological maps and of physical factors such as morphology.

\section{Geomorphological and geological characteristics of Tuscany}

Tuscany $\left(22,987 \mathrm{~km}^{2}\right)$ is a topographically complex region located in central Italy, with few plains, crossed by major mountain chains and dominated by hilly country given over to agriculture. The highest ridges are in the northern and eastern part of the region (Fig. 1). The northwestern part is characterized by mountains comprised of metamorphic rocks (Apuan Alps; Coli 1989) and by steep valleys with thick colluvial and alluvial deposits, while the eastern part is characterized by mountains mainly made up of sedimentary rocks and by intermontane basins filled with alluvial deposits. The central and southern parts are characterized by hilly ("Colline Metallifere") morphology with an isolated volcanic relief (i.e., Mt. Amiata) and flat plains (such as that of Maremma) or wide valley floors where the main rivers (Arno, Ombrone and Serchio) flow. Rolling gentle hills cover about two-thirds $(66.5 \%)$ of the region's total area and mountains a further $25.1 \%$, with the highest reliefs reaching $2000 \mathrm{~m}$ a.s.l. in elevation. Plains occupy $8.4 \%$ of the total area, mainly related to the Arno river alluvial plain. 


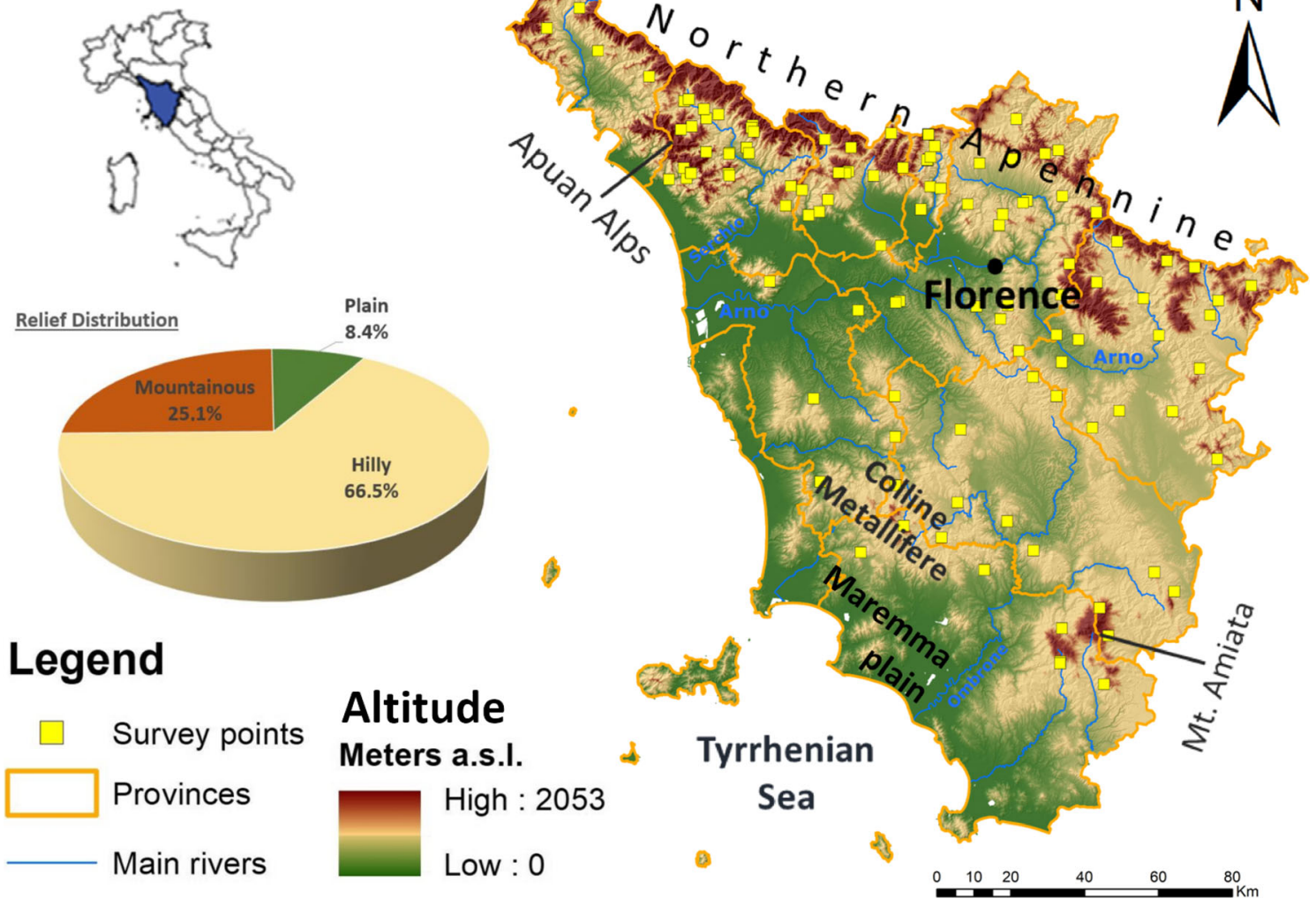

Fig. 1 Physiographic settings and relief distribution of the study area and location of survey points (yellow squares)

The main mountain chain in Tuscany is the Northern Apennine, a NE-verging fold-and-thrust orogenic belt that originated from the closure of the Jurassic "LigurePiemontese" Ocean, which began in the Cretaceous, and the subsequent Oligocene-Miocene collision between the continental Corso-Sardinian block and the Adria microplate (e.g., Boccaletti and Guazzone 1974). From the Oligocene to the present day, the Northern Apennine was affected by two stages of deformation that migrated eastward (e.g., Elter et al. 1975): an early phase characterized by a compressive stress, with the genesis of eastward-directed thrusts, and a later phase related to a still active extensional stress in the Tyrrhenian side. As a consequence of these two tectonic activities, several NW-SE trending basins opened (e.g., Bonini and Sani 2002) and, subsequently, these basins were filled by the sediments eroded from the sedimentary rocks still constituting the mountain chain. The deposits have been uplifted during the Quaternary and then modeled by superficial processes and river incisions. Therefore, the resulting hillslope deposits are nowadays thin to almost lacking on sharp ridges and steeply sloped terrains and thickest in wider valleys.

For this work, a lithological map of the bedrock was arranged (Fig. 2) by customizing the lithological map obtained from the geological map of Italy, 1:500,000 by ISPRA (Italian National Institute for Environmental Protection and Research). In most of the study area, the bedrock consists of arenaceous, calcareous and pelitic flysch units. These units have been classified within three different classes: "arenaceous-marly flysch (AMF)", "calcareous-marly flysch (CMF)" and "pelitic flysch (PF)", based on their prevalent lithological characteristics, as derived from regional geological maps. The geological units consisting of sedimentary, mainly carbonate, rocks originated from chemical precipitation have been classified within the class of "limestones, dolostones, travertines and evaporitic deposits (LDTE)". Poorly consolidated and/or altered sedimentary rocks rich in the finest fraction (i.e., clay) have been classified as "clay, claystones and marls (CCM)". Granular, unconsolidated geologically recent deposits (i.e., Quaternary or younger) have been assigned to the "granular deposits GD)" class. Lastly, the class "metamorphic and volcanic rocks (MVR)" combines a variety of lithological types with a small outcrop area extent.

\section{Sampling and geotechnical-hydrological-mineralogical characterization}

For this study, a total of 129 samples were collected in 102 different sites (data available from this paper and Pazzi et al. 2016; Tofani et al. 2017; see supplementary materials), in the period from October 2013 to June 2015 (Figs. 1, 2). The sites 


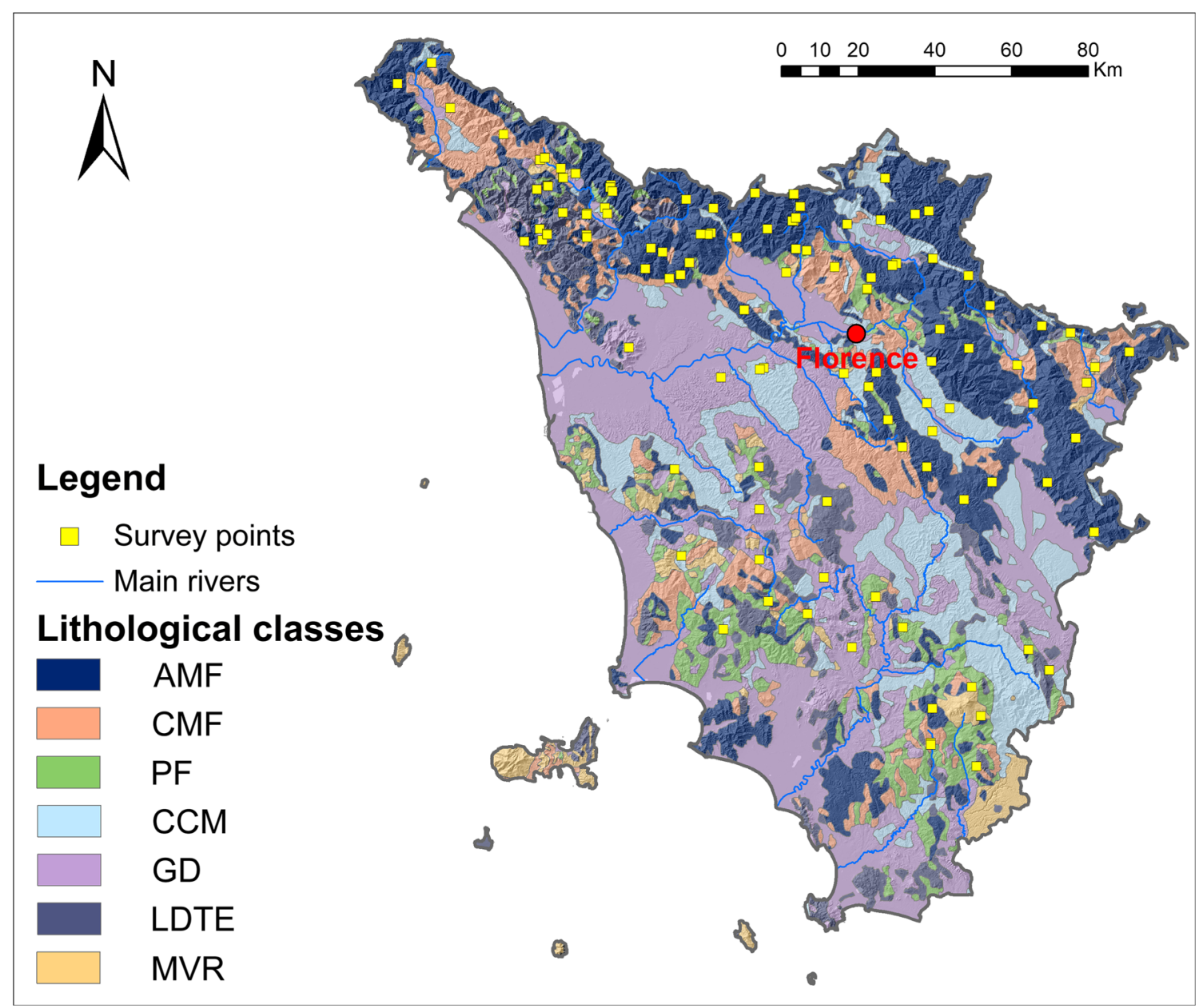

Fig. 2 A 7-class lithological map of Tuscany and the location of survey points (yellow squares); $A M F$ arenaceous-marly flysch, $C M F$ calcareousmarly flysch, $P F$ pelitic flysch, $C C M$ clay, claystones and marls, $G D$

granular deposits, LDTE limestones, dolomites, travertines and evaporitic deposits, $M V R$ metamorphic and volcanic rocks

have been selected in order to have a representative sample of the main soil types producing shallow landslides while trying to keep a homogenous spatial distribution across the hillslopes of Tuscany. Consequently, the investigated sites are not evenly divided with respect to the chosen bedrock lithological classes. The mean distance between each site of interest was between 10 and $15 \mathrm{~km}$. Samples were collected at depths ranging from 0.4 to $0.6 \mathrm{~m}$ below the ground surface, which is above the typical depth of shallow landslide failure planes (e.g., Dietrich et al. 2007).

The geotechnical and hydrological parameters for characterizing the soils were determined from in situ and laboratory tests. In particular, the in situ tests are: the Borehole Shear Test (BST; Luttenegger and Hallberg 1981; Dapporto et al. 2000) for measuring the soil shear strength parameters, a constant head permeameter test performed with the Amoozemeter instrument (Amoozegar 1989) and matric suction measurements with a tensiometer.

The BST instrumentation allows for the estimation of the shear strength parameters under natural conditions without disturbing the soil samples and is performed on soils in unsaturated conditions, which means that they are subject to pore water pressure $\left(\mathrm{u}_{\mathrm{w}}\right)$ conditions lower than that of air pressures $\left(u_{a}\right)$. At the same depth as the BST, matric suction values (u${ }_{a}-u_{w}$ ) were measured with tensiometers during field testing. BSTs for this work were performed within an interval of $\sigma$ values of 20-80 kPa (Bicocchi et al. 2015). For further information about the BST test in shallow deposits and the interpretation of the results, refer to Rinaldi and Casagli (1999), Casagli et al. (2006), and Tofani et al. (2006, 2017). The test allows to directly measure in situ the friction angle $\left(\varphi^{\prime}\right)$ and total cohesion (c) that is the sum of the effective cohesion (c') and the apparent cohesion due to the matric suction. Effective cohesion should be measured by mean of direct shear tests, which are not currently available for this study; indeed, laboratory shear tests are time consuming and to be performed in artificially reconstructed (i.e., "disturbed") samples, so that it is difficult to rearrange the sample to reproduce the other factors controlling the in situ conditions (such as the soil textures, soil aggregates and roots) and to compare laboratory data and 
field tests. In addition, a detailed analysis of the repartition of the total cohesion between apparent cohesion and effective cohesion is beyond the scope of this paper. However, the BSTs were performed at shallow depths on mostly granular, normal consolidated materials, so that $c^{\prime}$ could be reasonably assumed to be equal to $0 \mathrm{kPa}$ (Tofani et al. 2017). The error in the measurement of $\varphi^{\prime}$ was calculated considering the sensitivity of the BST manometer $(2 \mathrm{kPa})$ and the goodness of fit of the regression line ( $R^{2}$ values spanning from 0.92 to 0.99 ) used to retrieve the effective internal friction angle by interpolating the couples of $\sigma-\tau$ values measured. Overall, the error span was from $1.5^{\circ}$ to $3.5^{\circ}$ with a mean value of $2.0^{\circ}$.

The Amoozemeter or Compact Constant Head Permeameter has allowed the measurement of the saturated hydraulic conductivity $\left(\mathrm{k}_{\mathrm{s}}\right)$. The results have interpreted according to the Glover solution (Philip 1985; Casagli et al. 2006; Tofani et al. 2006).

To complete the characterization of the soils, laboratory tests were conducted at the Department of Earth Sciences, University of Florence, to determinate grain size distributions, Atterberg limits and soil phase relationships (bulk porosity $n$; saturated, natural and dry unit weight, $\gamma_{\text {sat }}, \gamma$ and $\gamma_{\mathrm{d}}$, respectively). Tests were performed following the ASTM (American Society for Testing and Materials) recommendations (ASTM D422-63 2007, ASTM D2217-85 1998 and ASTM D-4318 2010). Furthermore, on selected samples, representative of the different soils and bedrock lithologies of Tuscany, the mineralogical content was analyzed by means of XRPD (Xray powder diffraction). To this end, the bulk samples of soils were dried at $110^{\circ} \mathrm{C}$ for $24 \mathrm{~h}$ in an oven to remove moisture, then crushed and sieved down to $<64 \mu \mathrm{m}$, producing powder to be analyzed. The instrument employed at the Department of Earth Sciences, University of Florence, for XRPD analyses was a PHILIPS PW 3710, equipped with an X-Rays $\mathrm{Cu}$ anticathode tube with graphite filter. The analysis of the phyllosilicates in the clay fraction was carried out according to the method proposed by Cipriani (1958) and Banchelli et al. (1997).

\section{Results}

\section{Soil classification, grain size distributions, phase relations and Atterberg limits}

Due to their grain size distributions (Fig. 3), the analyzed deposits are to be mostly classified as well-sorted siltyclayey sands, i.e., SW, SM, SC and SM-SC classes with respect to the Unified Soil Classification System (USCS; Wagner 1957). However, a non-negligible part of the samples (Fig. 4) is characterized by higher contents of silt and clay (ML, CL, CH and OL classes in the USCS), whilst an isolated sample is classified as GW.

Fig. 3 Ternary diagram of gravel, sand, silt and clay fraction in the analyzed samples; the lithology of the bedrock underlying the soils is taken from the lithological map (Fig. 2) and shown by differentg colors; $A M F$ arenaceous-marly flysch, $C M F$ calcareous-marly flysch, $P F$ pelitic flysch, $C C M$ clay, claystones and marls, $G D$ granular deposits, LDTE limestones, dolomites, travertines and evaporitic deposits, $M V R$ metamorphic and volcanic rocks

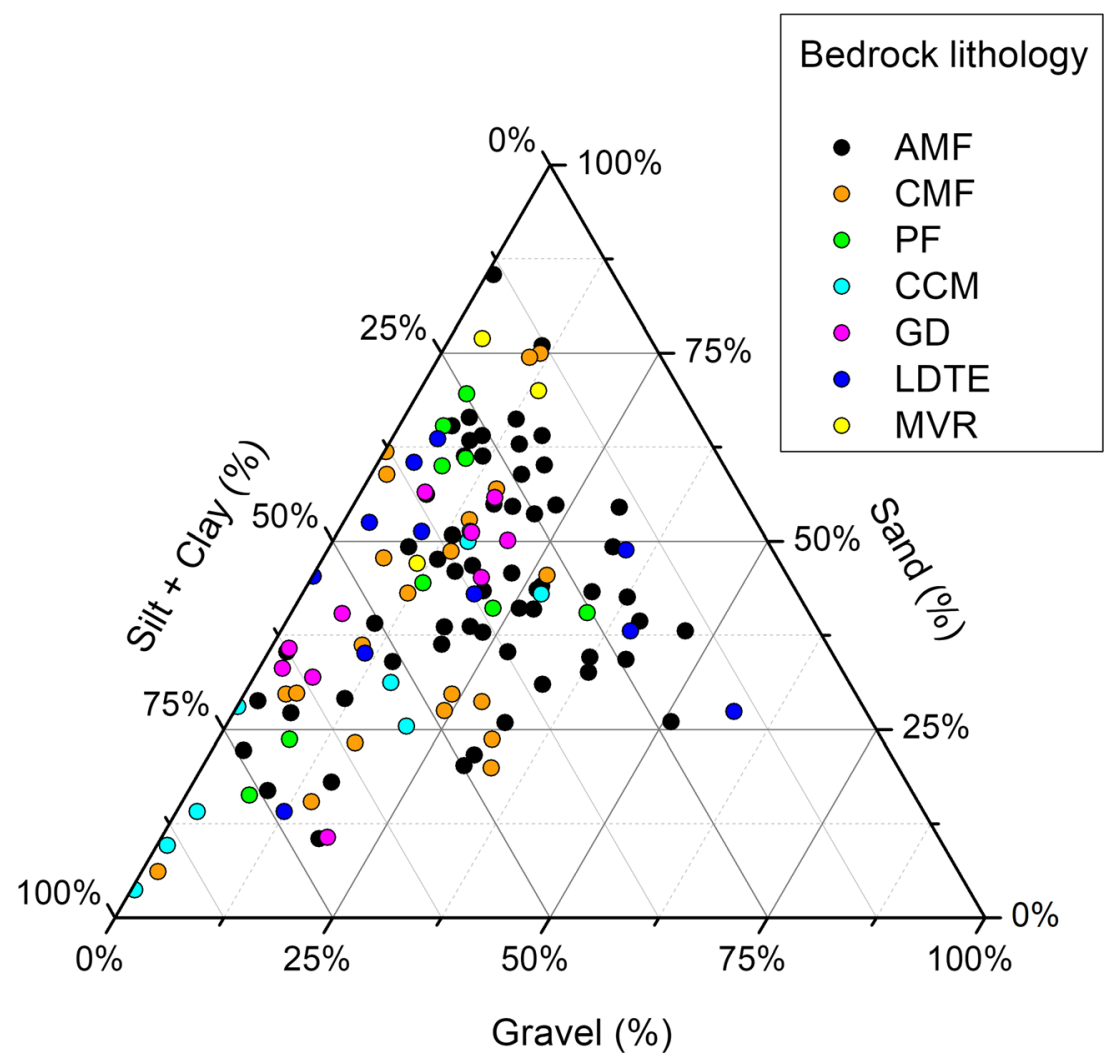


Fig. 4 USCS classes occurrence in the analyzed samples. USCS acronyms are explained in the Appendix

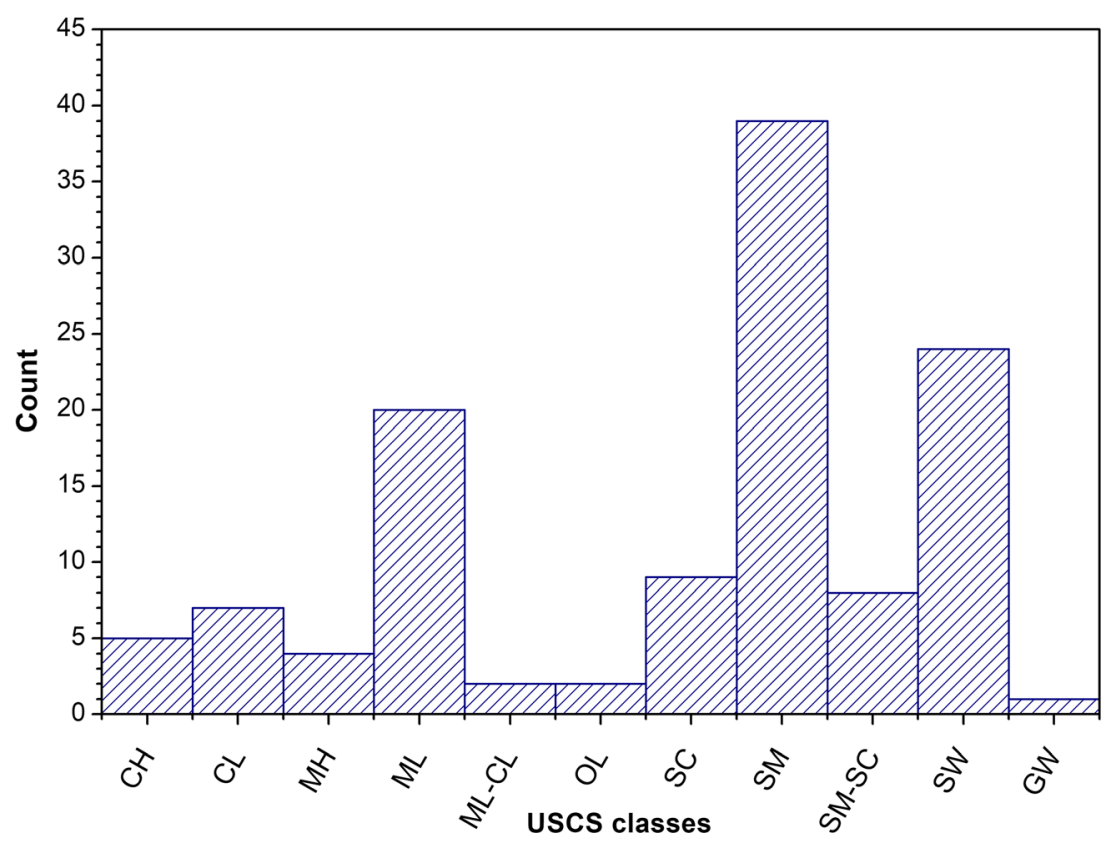

The dry unit weight $\left(\gamma_{\mathrm{d}}\right)$ ranges between 10.7 and 20.8 $\mathrm{kN} \mathrm{m}^{-3}$, but the majority of the values lie in a narrower interval between 15 and $17 \mathrm{kN} \mathrm{m}^{-3}$, with a mean value of $15.5 \mathrm{kN} \mathrm{m}^{-3}$ (Fig. 5a; Table 1). The bulk porosity values span a wide interval: from $19.9 \%$ to $58.8 \%$ with a median value of $38.8 \%$ (Fig. 5 b; Table 1). These results are in line with the prevalent soil type of silty-clayey sands (e.g., Rawls et al. 1982).
As far as it concerns the values of the Atterberg limits, we found that the highest plastic (PL) and liquid (LL) limits, as well as the highest plasticity index (PI)-respectively, 58, 40 and 33 - are related to clay-rich samples $(\mathrm{CH}$ and $\mathrm{MH}$ in USCS classification). However, overall PL, LL and PI cluster around (median values) 36, 27 and 10, respectively, i.e., the soils mostly show a low plastic behavior as indicated from the position of the samples in the Casagrande Plasticity Chart (Fig. 6).
Fig. 5 (a) $\gamma_{d}$ (dry unit weight), (b) n (bulk porosity), (c) $\varphi^{\prime}$ (internal effective friction angle), (d) log- $k_{s}$ (saturated hydraulic conductivity)
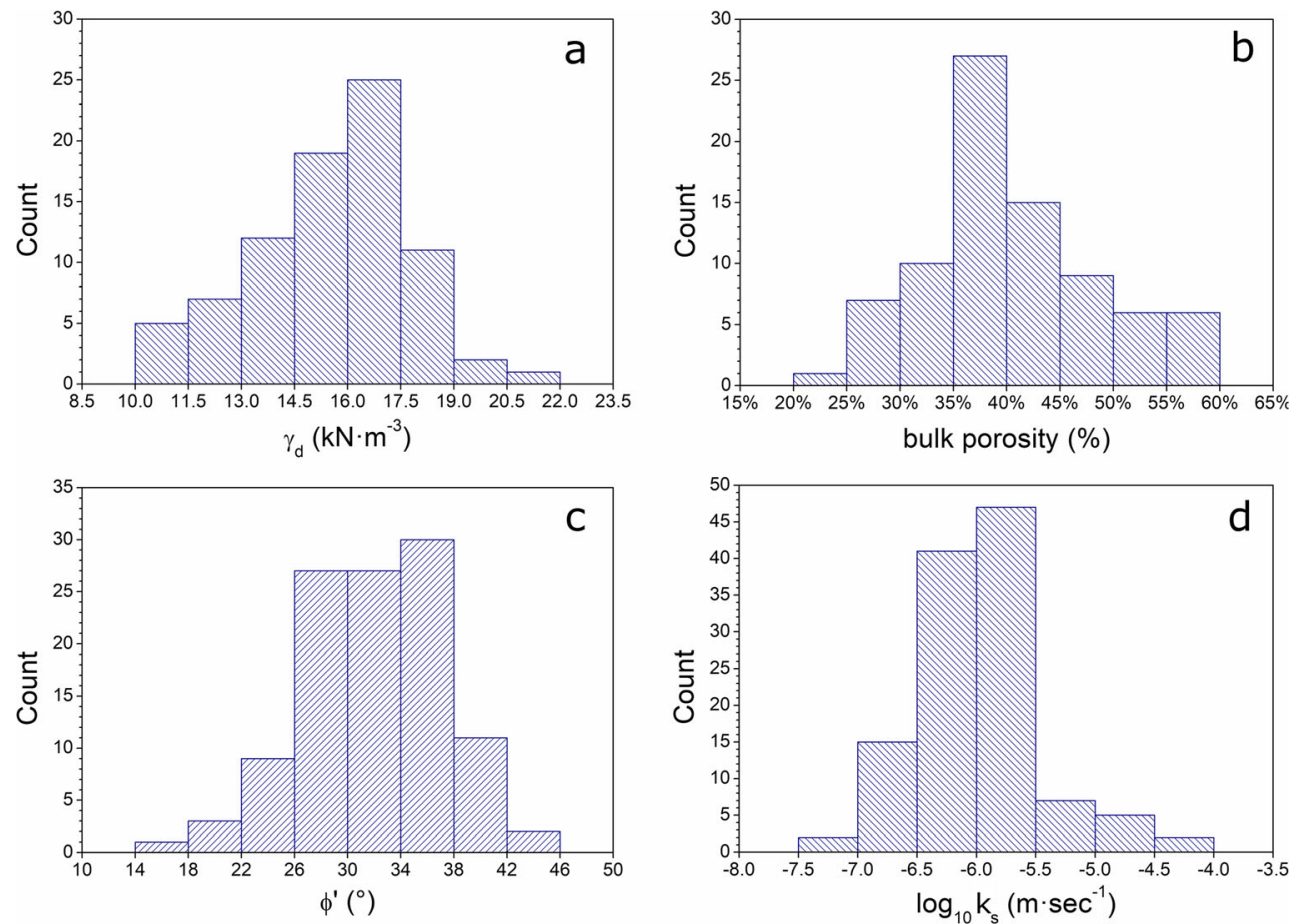
Table 1 Main statistical properties of relevant geotechnical parameters

\begin{tabular}{lllll}
\hline & $\gamma_{\mathrm{d}}\left(\mathrm{kN} \mathrm{m}^{-3}\right)$ & $\mathrm{n}(\%)$ & $\varphi^{\prime}\left({ }^{\circ}\right)$ & $\mathrm{k}_{\mathrm{s}}\left(\mathrm{m} \mathrm{s}^{-1}\right)$ \\
\hline Min & 10.7 & $19.9 \%$ & 15 & $4 . \mathrm{E}-08$ \\
Max & 20.8 & $58.8 \%$ & 45 & $8 . \mathrm{E}-05$ \\
Arithmetic mean & 15.5 & $40.2 \%$ & 32 & $3 . \mathrm{E}-06$ \\
Geometric mean & 15.4 & $39.3 \%$ & 31 & $1 . \mathrm{E}-06$ \\
Median & 15.9 & $38.8 \%$ & 32 & $1 . \mathrm{E}-06$ \\
\hline
\end{tabular}

$\gamma_{\mathrm{d}}$ dry unit weight, $n$ bulk porosity, $\varphi^{\prime}$ internal effective friction angle, $k_{\mathrm{s}}$ saturated hydraulic conductivity

\section{Mineralogical composition of the samples}

In the 25 analyzed samples (data available from this paper and Masi 2016), six main mineralogical phases were recognized: quartz (in $96 \%$ of the samples), k-feldspars (44\% of the samples), plagioclase ( $100 \%$ of the samples, as albite), mica (biotite and muscovite, $92 \%$ of the samples), calcite ( $52 \%$ of the samples) and a mixture of various clay minerals ( $92 \%$ of the samples). In addition, the presence of gypsum, hematite, amphiboles and chrysotile were detected in a few cases. On 15 clay-rich samples of soils, specific analyses were aimed at recognizing the different clay minerals that were not clearly distinguished in the former analyses on the bulk samples powder. These phases were: illite, kaolinite, chlorite, vermiculite and, in some cases, layers of I-M (Illite and Montmorillonite, also known as "smectite") and C-V (Chlorite-Vermiculite).

\section{A compositional statistical analysis of grain size distributions}

To provide a more detailed insight into the grain size distribution, a quantitative assessment through compositional statistics has been carried out. Theory and practice of such a

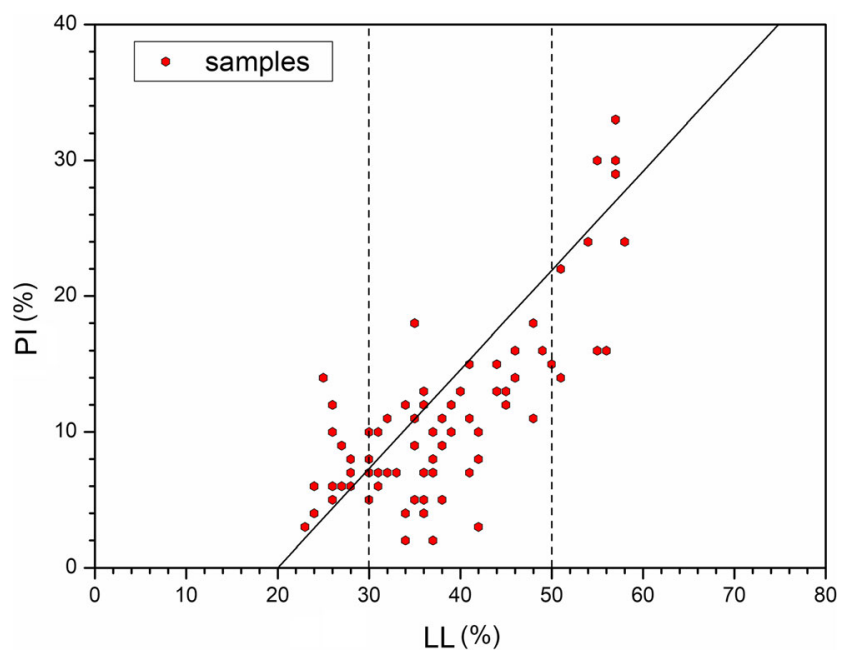

Fig. 6 Casagrande Plasticity Chart of the analyzed soils; PI plasticity index, $L L$ liquid limit compositional statistical approach in the Earth Sciences can be found in Thomas and Aitchison (2005), Buccianti (2013), and, in particular, when treating grain size distributions, in von Eynatten (2004). When quantitatively assessing compositional data, such as chemical composition of fluids and rocks, or, as in this work, grain size distribution, an appropriate measure of central tendency may be represented by the closed (i.e., a vector normalized to a fixed sum $k$ ) geometric mean $\mathrm{g}_{c}$. The latter, for a compositional dataset of $\mathrm{D}$ variables or parts (which in this study are represented by the values of the four grain size fractions, i.e., gravel, sand, silt, and clay), abundances (expressed as \% by weight) and dimension $n$ (i.e., number of data or samples) is called "center" and is defined as follows:

$g_{c}=C\left(g_{1}, g_{2}, \ldots, g_{D}\right)$

where $\mathrm{C}$ stands for the closure operation, which is defined for any vector of $\mathrm{D}$ real positive components $z=\left[z_{1}, z_{2}\right.$, $\left.\ldots, z_{D}\right]$ as:

$\mathrm{C}(\mathrm{z})=\left[\frac{k \cdot z_{1}}{\sum_{i=1}^{D} z_{i}}, \frac{k \cdot z_{2}}{\sum_{i=1}^{D} z_{i}}, \ldots, \frac{k \cdot z_{D}}{\sum_{i=1}^{D} z_{i}}\right]$

and $g$ (the geometric mean) is calculated as follows:

$\mathrm{g}_{\mathrm{i}}=\left(\prod_{J=1}^{\mathrm{n}} \mathrm{x}_{\mathrm{ij}}\right)^{\frac{1}{n}}, \mathrm{i}=1,2, \ldots, \mathrm{D}$.

For the dataset presented in this work, the center of the 4part composition investigated (i.e., the grain size distribution) is the following: $\mathrm{GR}=12.5 \%, \mathrm{SA}=45.9 \%, \mathrm{SI}=32.8 \%$ and $\mathrm{CL}=8.8 \%$, where $\mathrm{GR}=$ gravel, $\mathrm{SA}=$ sand, $\mathrm{SI}=$ silt and $\mathrm{CL}=$ clay. The center values are consistent with the occurrence of the majority of the analyzed samples within SW and SM USCS classes (Fig. 4), but center lack in giving information about the variability in the analyzed dataset. Thus, in a further step, we focus on the relationship between parts of the composition, which are the real matter of interest when treating compositional data (e.g., Aitchison 2003). To give information about both the mean values of log-ratios between all parts (representing the barycenter of the data) and the variances of the same log-ratios (which give a measure of dispersion of the values around the barycenter), the "variation array" (Table 2) is used. At the end of each row of the variation array (Table 2), the clr (centered log-ratio) variance for each part is also added (i.e., the variance evaluated for each grain size fraction after a centered log ratio transformation). The centered log-ratio transformation (Aitchison 2003) is defined as:

$\operatorname{clr}(\mathrm{x})=\mathrm{y}=\left[\mathrm{y}_{1}, \mathrm{y}_{2}, \ldots, \mathrm{y}_{\mathrm{D}}\right]$ 
Table 2 Variation array of hillslope material grain size distributions

\begin{tabular}{c|c|c|c|c|c}
\multicolumn{2}{l|}{} & \multicolumn{3}{c|}{ Variance $\ln \left(\mathrm{X}_{\mathrm{i}} / \mathrm{X}_{\mathrm{j}}\right)$} & \\
\hline $\mathrm{X}_{\mathrm{i}} / \mathrm{X}_{\mathrm{j}}$ & Gravel & Sand & Silt & Clay & clr variances \\
\hline Gravel & - & 1.69 & 1.99 & $3.19^{\mathrm{a}}$ & 1.09 \\
\hline Sand & 1.30 & - & $0.70^{\mathrm{b}}$ & 1.80 & 0.42 \\
\hline Silt & 0.97 & -0.33 & - & $0.66^{\mathrm{b}}$ & 0.21 \\
\hline Clay & -0.34 & -1.64 & -1.31 & - & 0.78 \\
\hline & \multicolumn{3}{|c|}{ Mean $\ln (\mathrm{Xi} / \mathrm{Xj})$} & & $2.50^{\mathrm{c}}$
\end{tabular}

The variation array was computed with Codapack v.2.01.15 (Comas-Cufí and Thió-Henestrosa 2011). In the upper-right half of the matrix are reported the log-ratio variances, while in the lower half are reported the arithmetic means of the log-ratios. At the end of each row, the clrvariances (centered-log-ratio variances) for each part are shown

${ }^{\text {a }}$ Highest log-ratio variance value

${ }^{\mathrm{b}}$ Lowest log-ratio variance values

${ }^{\mathrm{c}}$ Total variance

where

$\mathrm{y}_{\mathrm{i}}=\left[\ln \frac{\mathrm{x}_{1}}{\mathrm{~g}(\mathrm{x})}, \ln \frac{\mathrm{x}_{2}}{\mathrm{~g}(\mathrm{x})}, \ldots, \ln \frac{\mathrm{x}_{\mathrm{D}}}{\mathrm{g}(\mathrm{x})}\right]$

and $g(x)$ is the geometric mean of the components of the compositional vector $\mathrm{x}$.

In the dataset, the higher variance is contained in the gravel/ clay log-ratio (3.19), while the lower variances are associated with the sand/silt and silt/clay log-ratios $(0.66-0.70)$. The values of the single component clr-variances highlight that the gravel and clay fractions explain most of the total variance (more than the $70 \%$ ), while sand and silt are associated to $\sim 25 \%$ of the total variance.

\section{Shear strength parameters, matric suction and saturated hydraulic conductivity}

The shear strength is measured in situ so that it is assessed in the context of their saturation state, which can be inferred by the matric suction measures (e.g., Fredlund et al. 1978; Fredlund and Rahardjo 1993). With respect to the matric suction values, we can split in two subsets the samples: those with values from 1.4 to $5 \mathrm{kPa}$, thus associated to saturated to slightly unsaturated soils, and those characterized by matric suction from 5 to over $80 \mathrm{kPa}$, which are in a state of undersaturation. While the internal effective friction angles $\left(\varphi^{\prime}\right)$, whose measured values span from $15^{\circ}$ to $45^{\circ}$ with an average value of $32^{\circ}$ (Fig. 5c; Table 1), is not directly controlled by water content and saturation, the total cohesion (c) depends on the degree of saturation and matric suction. Indeed, values of $\mathrm{c}$ span from $23 \mathrm{kPa}$ for highly unsaturated soils with high matric suctions (up to $90 \mathrm{kPa}$ ) to $0 \mathrm{kPa}$ for saturated soils. The hydraulic conductivity $\left(\mathrm{k}_{\mathrm{s}}\right)$ is measured after reaching the saturation of the soils so that, as for the $\varphi^{\prime}$, it is performed at standard conditions and does not depend on the water content and saturation of the soils. The values of $\mathrm{k}_{\mathrm{s}}$ range in a wide interval from $410^{-8} \mathrm{~m} \mathrm{~s}^{-1}$ to $810^{-5} \mathrm{~m} \mathrm{~s}^{-1}$, but cluster between $10^{-7} \mathrm{~m} \mathrm{~s}^{-1}$ and $310^{-6} \mathrm{~m} \mathrm{~s}^{-1}$ (Fig. 5d).

\section{Discussion}

\section{Processes governing the grain size distribution of soils}

The main processes governing the production of the regolith from bedrocks are physical and chemical weathering (e.g., Goudie 2003; Goudie and Viles 2008; Calcaterra and Parise 2010 and references therein). Moreover, soils contained in the hillslope deposits (i.e., the colluvium) are frequently affected by erosion, transport and deposition promoted by water runoff that controls the relative deposits enrichment or depletion with respect to the different granulometric fractions (Taylor and Eggleton 2001) and the shape of the hillslopes (e.g., Heimsath et al. 1997). In addition to these kinds of processes, mass movements may interest and modify the shape of hillslope deposits. Indeed, colluvium on the hillslopes may become mechanically unstable at the depth of $\sim 1.5 \mathrm{~m}$ triggering shallow landsliding as debris flows, which ultimately leads to soil transport along the hillslopes (Benda and Dunne 1997).

The statistical analysis of grain size distribution (Section 4.3) highlights that the sand/silt and silt/clay log-ratio are those characterized by the lowest variance in the deposits (upper-right half matrix of the variation array, Table 2). Low variances in these ratios indicate that the proportions between the sand, silt, and clay grain size fractions, independently from their relative abundances, is preserved in the deposits. As a consequence, sand to silt and silt to clay transformation should be constrained to relatively constant values (i.e., the mean values of logratios, lower-left half matrix of the variation array, Table 2) by processes, acting extensively in all the deposits investigated, which maintain a similar proportion between the grain size fractions. Physical alteration of colluvium and runoff-driven transport of soils are generally addressed as responsible for sand to silt transformation (Moss and Green 1975; Wright et al. 1998). These two processes are widespread, strongly control the hillslope dynamics and could be responsible for the observed, fairly constant, proportion between sand and silt fractions. Instead, we can explain the higher variability of the gravel to sand ratio by considering that gravel is derived from local bedrock weathering (i.e., the breakdown of parent 
rock into smaller gravel, sand and silt size fractions). Indeed, gravel abundance in the deposit overlying the bedrock is more likely dependent on the alteration of the bedrock itself, which is in its turn quite variable because it is also extremely dependent upon the type of bedrock. Moreover, the gravel fraction can be more efficiently transported alongside relatively less frequent heavy rainfall or isolated, local debris-flow events than by everyday runoff.

The bulk mineralogical composition of soils (mainly consisting of chemical alteration-resilient tectosilicates such as quartz and feldspars) confirms that most parts of mineral phases are inherited from the bedrock after it is physically altered (e.g., Certini et al. 2003). In that perspective, we can also explain the unusual presence of gypsum and chrysotile because of the uncommon mineralogical composition of some types of bedrock, such as evaporitic layers for gypsum or metamorphic rocks for chrysotile. Instead, silt to clay clast transformation is more likely to be related to chemical alteration, with the formation of secondary minerals, such as the authigenic phyllosilicates we found in the clay fraction of the deposits (e.g., Churchman and Lowe 2012). This could explain the fairly low variance associated to silt/clay log-ratio.

\section{Relationship between geotechnical and hydrological parameters and bedrock lithology}

In this section, the relationship between parameters of soil deposits and bedrock lithology is examined. The outcropping extension, the number of survey points and the soil classification based on USCS for each lithological class are reported in Table 3 .

For each bedrock lithological class, we have analyzed the soil classification, according to USCS classification (Table 3; Fig. 7). AMF, CMF, LDTE, and PF have mainly silty sands and clayey sands soil deposits. CCM and GD show silty soils with low and high plasticity. MVR are overlain mainly by well-sorted sands, but as the MVR class consist of only three observations, this should be considered statistically poorly significant.

The variability of the main geotechnical and hydrological parameters $\left(\varphi^{\prime}, \gamma_{\mathrm{d}}\right.$ and $\left.\mathrm{k}_{\mathrm{s}}\right)$ is inspected by using box plots, where the parameters are aggregated by using the bedrock lithological classes (excluded MVR class which lacks data; Fig. 8a-c) and then for USCS classes (Fig. 9a-c). The boxes consist of a central line representing the median (50th percentile or second quartile), the circle stands for the arithmetic mean and the top and bottom of the boxplot are aligned with the 25th and 75th percentiles (or first and third quartiles) while the whiskers extend to the maximum and minimum data.

Starting from the aggregation based on bedrock lithology, it is possible to see that the boxes of effective friction angle (Fig. 8a) are quite symmetric, as the median is very similar to the arithmetic mean. Indeed, as shown by a normality test (Table 4), for all the bedrock classes we can assume $(p>0.05)$ the use of a gaussian model for the frequency distribution. However, we should note that, for small-sized classes $(<20$ samples), normality tests have little power to reject the null hypothesis and therefore small samples most often pass normality tests even if their frequency distribution shape does not resemble that of a gaussian curve.

Concerning the dry unit weight, box plots (Fig. 8b) are symmetric in their shape, apart for the GD and LDTE classes, with median and arithmetic mean values very close and the space between the quartiles homogeneously distributed. Normality tests, performed on AMF and CMF, attest that a gaussian distribution can be used to describe the frequency distribution.

Eventually, concerning the $\mathrm{k}_{\mathrm{s}}$ values (Fig. 8c), they were log-transformed prior to box-plotting and normality tests, since the significance of these kinds of measurements resides in the order of magnitude of the measured values, rather than in the whole value. Conductivity values show some distinctive asymmetric distribution with respect to the arithmetic mean values, which are located far above the median and often above the 3rd quartile (i.e., the upper box limits). In most of the cases (CMF, LDTE and GD) a log-normal gaussian model
Table 3 Number of survey points for each lithological class and soil classification according to USCS

\begin{tabular}{|c|c|c|c|c|c|c|}
\hline $\begin{array}{l}\text { bedrock } \\
\text { lithological class }\end{array}$ & $\begin{array}{l}\text { outcrop extent } \\
\text { in Tuscany }\left(\mathrm{km}^{2}\right)\end{array}$ & $\mathrm{n}^{\circ}$ of surveys & SW & $\mathrm{SM}+\mathrm{SC}$ & $\mathrm{ML}+\mathrm{MH}$ & $\mathrm{CL}+\mathrm{CH}+\mathrm{OL}$ \\
\hline $\mathrm{AMF}$ & 6036 & 57 & 18 & 27 & 9 & 3 \\
\hline CMF & 2235 & 21 & 0 & 11 & 5 & 5 \\
\hline $\mathrm{CCM}$ & 3269 & 9 & 0 & 3 & 4 & 2 \\
\hline GD & 7234 & 11 & 1 & 3 & 4 & 3 \\
\hline LDTE & 1674 & 11 & 2 & 6 & 2 & 1 \\
\hline MVR & 797 & 3 & 2 & 1 & 0 & 0 \\
\hline PF & 1718 & 8 & 1 & 5 & 2 & 0 \\
\hline
\end{tabular}

$A M F$ arenaceous-marly flysch, $C M F$ calcareous-marly flysch, $P F$ pelitic flysch, $C C M$ clay, claystones and marls, $G D$ granular deposits, LDTE limestones, dolomites, travertines and evaporitic deposits, MVR metamorphic and volcanic rocks 
Fig. 7 Pie charts showing the distribution of soil types for different lithologies; $A M F$ arenaceous-marly flysch, $C M F$ calcareous-marly flysch, $P F$ pelitic flysch, $C C M$ clay, claystones and marls, $G D$ granular deposits, $L D T E$ limestones, dolomites, travertines and evaporitic deposits, $M V R$ metamorphic and volcanic rocks Note that a single sample classified as GW is not considered in these statistics. USCS acronyms are explained in the Appendix (aggregated USCS classification)
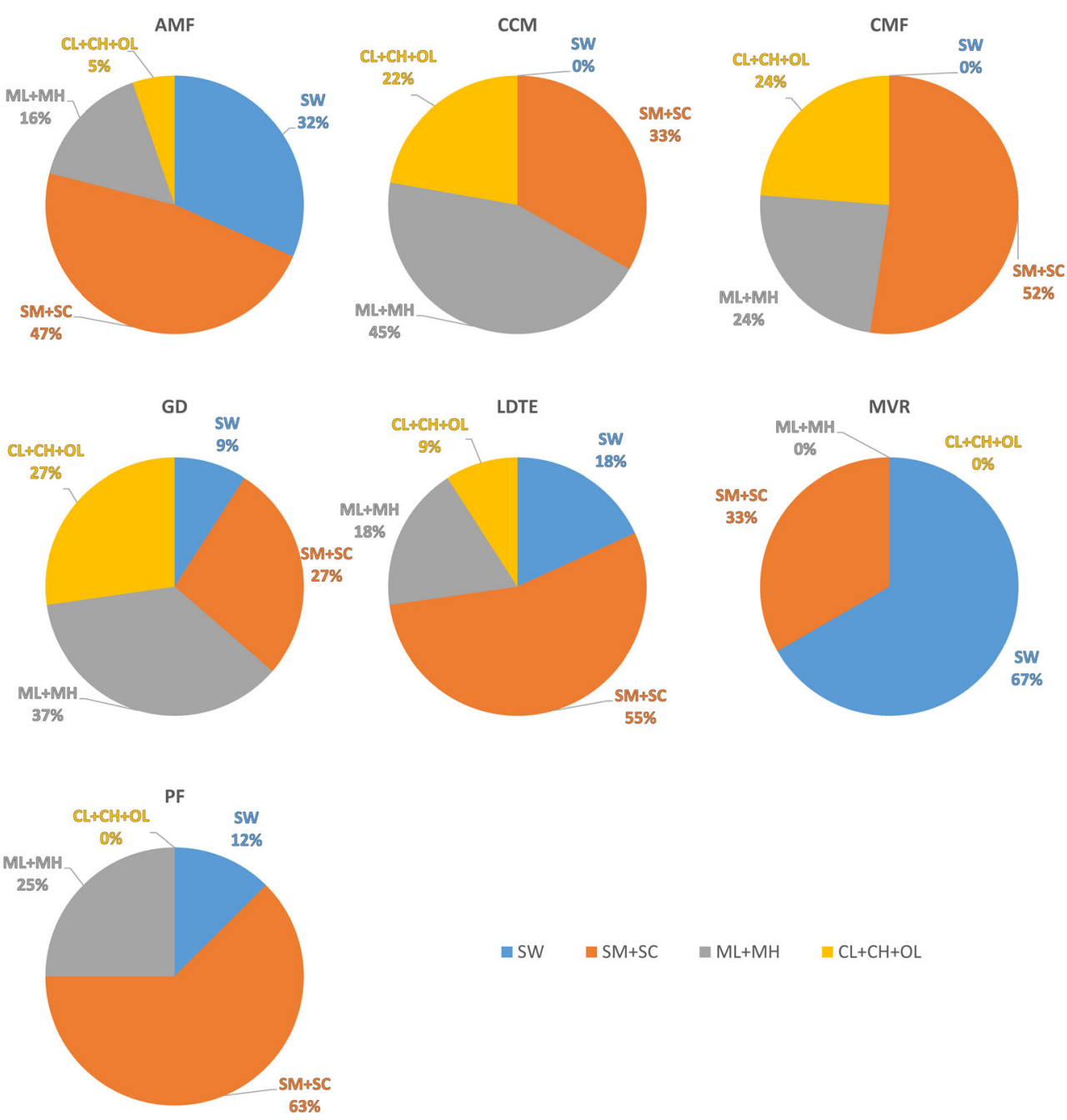

can be adopted for the frequency distribution. The most populated bedrock lithological class (AMF) fails the normality test $(p<0.05)$, possibly because of the presence of a subset of data with relatively high values between $10^{-5}$ and $10^{-4} \mathrm{~m}$ $\mathrm{s}^{-1}$. Conceivably, this subset represents a population of high permeable soils that was impossible to characterize properly through the available data.

An interesting finding of this study is that, in the study area, a reliable extrapolation of soil parameters is quite difficult to achieve based on the simple observation of the underneath bedrock lithology. As a matter of fact, despite most of the samples in this study being classified within the field of AMF, important differences have been found concerning their grain size distribution, especially regarding the gravel and clay fractions (Fig. 7). The main reasons for such decoupling between the bedrock type and the deposit and regolith granulometry could be that: (1) the deposits may have originated from a different bedrock with respect to what they overlie at present, and especially (2) most of the geological units of the Northern Apennine are quite heterogeneous and intrinsically complex flysch (e.g., Martini and Vai 2001), often characterized by repeated lithological changes (e.g., sandstone to claystone and/or to limestone) in a few tens of meters, so that the characteristics of the regolith, from which the deposits formed, may vary as the bedrock lithological changes occurs.

If we look at the distribution of values aggregating the data on the base of USCS classes, the box plots for the friction angle (Fig. 9a) show that the distribution of values is quite symmetric, especially for SM-SC and SW classes, although the range of the values covers over $20^{\circ}$. Conversely, the $\mathrm{ML}+\mathrm{MH}$ box plot is asymmetric, because of the short distances between the box upper limit and the maximum values while the distance between the lower limit and minimum values is quite high (over $10^{\circ}$ ).

Dry unit weight box plots (Fig. 9b) are symmetric in their shape, apart from SW and secondarily for $\mathrm{CL}+\mathrm{CH}+\mathrm{OL}$, but the values are extremely dispersed (e.g., SM + SC class values range up to $100 \%$, from less than 11 to more than $20 \mathrm{kN} \mathrm{m}^{-3}$ ).

Lastly, $\mathrm{k}_{\mathrm{s}}$ values (Fig. 9c), as for the data aggregated by bedrock class, were log-transformed prior to making up the box plots. Once again, the conductivity values are 

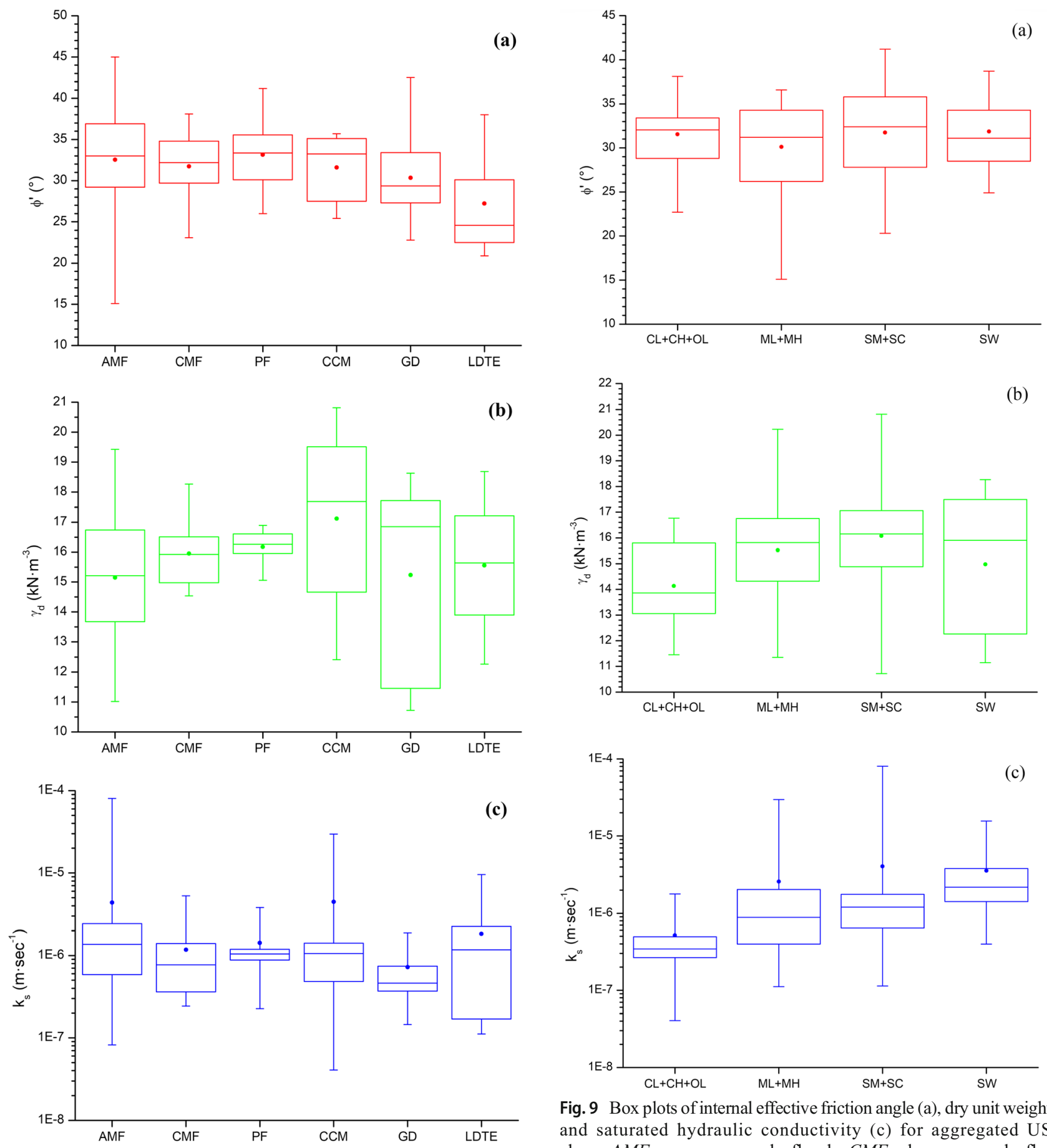

Fig. 9 Box plots of internal effective friction angle (a), dry unit weight (b) and saturated hydraulic conductivity (c) for aggregated USCS classes $A M F$ arenaceous-marly flysch, $C M F$ calcareous-marly flysch, $P F$ pelitic flysch, $C C M$ clay, claystones and marls, $G D$ granular deposits, LDTE limestones, dolomites, travertines and evaporitic deposits, MVR metamorphic and volcanic rocks. The dot is the arithmetic mean value. USCS acronyms are explained in the Appendix unit weight), and (c) $\mathrm{k}_{\mathrm{s}}$ (saturated hydraulic conductivity) for different bedrock lithologies; $A M F$ arenaceous-marly flysch, $C M F$ calcareousmarly flysch, $P F$ pelitic flysch, $C C M$ clay, claystones and marls, $G D$ granular deposits, $L D T E$ limestones, dolomites, travertines and evaporitic deposits, MVR metamorphic and volcanic rocks. The dot is the arithmetic mean value

asymmetrically distributed with respect to the arithmetic mean values, which are located far above the median and often above the 3 rd quartile (i.e., the upper box limits). Those of $\mathrm{SW}$ and of the fine-sized classes $(\mathrm{CL}+\mathrm{CH}+\mathrm{OL})$ are the two

boxes with the smaller difference between the 1st and 3rd quartiles, that is, $50 \%$ of the values definitely span a lower range (7-9 $10^{-5}$ and $6-810^{-6} \mathrm{~m} \mathrm{~s}^{-1}$ ) with respect to the other classes. When aggregating the data by using USC classes, it is shown by the normality tests (Table 5) that the parameters for sandy soils (SM, SC and SW) are generally more suitable to 
Table 4 Number of measurements of internal effective friction angle, saturated hydraulic conductivity and dry unit weight with respect to lithological classes, including a normality test (Shapiro-Wilk test, Shapiro and Wilk 1965)

\begin{tabular}{llccccccc}
\hline Parameters & Bedrock lithological class & AMF & CMF & PF & CCM & GD & LDTE & MVR \\
\hline$\varphi^{\prime}\left(^{\circ}\right)$ & Sample size & 51 & 21 & 8 & 8 & 10 & 9 & 3 \\
& $p$ (normal) & 0.23 & 0.60 & n.d. & n.d. & 0.48 & n.d. & n.d. \\
$\gamma_{\mathrm{d}}\left(\mathrm{kN} \mathrm{m}^{-3}\right)$ & Sample size & 43 & 11 & 6 & 8 & 7 & 4 & 3 \\
& $p$ (normal) & 0.57 & 0.61 & n.d. & n.d. & n.d. & n.d. & n.d. \\
$\mathrm{k}_{\mathrm{s}}\left(\mathrm{m} \mathrm{s}^{-1}\right)$ & Sample size & 58 & 20 & 9 & 8 & 10 & 11 & 3 \\
& $p$ (normal) on & 0.02 & 0.38 & n.d. & n.d. & 0.30 & 0.37 & n.d. \\
& log-transformed data & & & & & & & \\
\hline
\end{tabular}

n.d. not determined be described by a (log)-normal frequency model with respect to the clay-rich soils $(\mathrm{CL}, \mathrm{CH}, \mathrm{OL})$. However, it is worth noting that for the saturated conductivity we can accept the hypothesis of (log)-normality only for SW while we have to refuse this hypothesis for the SC + SM. In the latter category, the presence of fine silty-clay matrix probably exerts some type of control on the hydraulic properties so that the frequency distribution of $\mathrm{k}_{\mathrm{s}}$ values of $\mathrm{SC}+\mathrm{SM}$ classes is no longer describable with a log-normal probability density function.

Compared to the analysis performed by aggregating the values by bedrock lithology, the use of USCS classes, especially looking at $\mathrm{SW}$ and $\mathrm{CL}+\mathrm{CH}+\mathrm{OL}$ for the $\varphi^{\prime}$ and $\mathrm{k}_{\mathrm{S}}$, appear to be more suitable for producing a symmetric distribution and a homogeneous division of the values, while both approaches substantially fail in finding an appropriate way to describe the distribution of dry unit weight box plots. Indeed, this parameter is probably the most sensitive, among the three analyzed here, to soil structure and vegetation cover controls, which have so far not been taken into account.

\section{Relationship of parameters with morphometric attributes}

In this section, we investigate the relationship between the soil type, in terms of USCS classification, and morphometric attributes with particular reference to slope gradient, profile curvature, planar curvature and peak distance (Fig. 10). We have computed these parameters using a 10-m resolution DEM through a set of GIS-based standard operations. Profile curvature is parallel to the direction of steepest descent and affects the acceleration or deceleration of flow across the hillslope surface. Planar curvature is perpendicular to the direction of steepest descent and relates to the convergence and divergence of flow across a surface. After the application of a $5 \times 5$ moving window median filter computed according to Tucker et al. (2001), a five-class classification was adopted, as reported in Fig. 10 for both curvature types. A moving window of $3 \times 3$ has also been used to apply a median filter to smooth the slope angles and to avoid local effects. Moreover, to estimate the actual distribution of the soil classes the frequency of occurrence within each morphometric class and to avoid problems related to sample size, we have normalized to $100 \%$ the number of samples of each morphometric class.

Even though the number of samples is limited and most of the samples are composed of silty sand (SM, Fig. 4), we can observe some typical behavior in the distribution of soil types for each morphometric parameter (Fig. 10).

In Fig. 10a, the distribution of the soil types with regard to the slope gradient is shown. In general, at low slope angles, granular soils $(\mathrm{SW}+\mathrm{GW}, \mathrm{SM}+\mathrm{SC})$ are predominant, while with the increase of slope angle, the presence of cohesive soils (ML + $\mathrm{MH}, \mathrm{CL}+\mathrm{CH}+\mathrm{OL}$ ) increases proportionally. This behavior can be related to the predominance of cohesive forces with respect to frictional ones from low to high slope gradients.

Concerning profile curvature (Fig. 10b), it is worth noting that in convex areas granular soils $(\mathrm{SW}+\mathrm{GW}, \mathrm{SM}+\mathrm{SC})$ are
Table 5 Number of measurements of internal effective friction angle, saturated hydraulic conductivity and dry unit weight with respect to USCS aggregated classes, including a normality test (Shapiro-Wilk test, Shapiro and Wilk 1965)

\begin{tabular}{lllccc}
\hline Parameters & USCS classes & $\mathrm{CL}+\mathrm{CH}+\mathrm{OL}$ & $\mathrm{ML}+\mathrm{MH}$ & $\mathrm{SM}+\mathrm{SC}$ & $\mathrm{SW}$ \\
\hline$\varphi^{\prime}\left(^{\circ}\right)$ & Sample size & 14 & 22 & 47 & 17 \\
& $p$ (normal) & 0.88 & 0.05 & 0.29 & 0.37 \\
$\gamma_{\mathrm{d}}\left(\mathrm{kN} \mathrm{m}^{-3}\right)$ & Sample size & 6 & 16 & 35 & 17 \\
& $p$ (normal) & n.d. & 0.87 & 0.26 & 0.04 \\
$\mathrm{k}_{\mathrm{s}}\left(\mathrm{m} \mathrm{s}^{-1}\right)$ & Sample size & 14 & 22 & 50 & 24 \\
& $p$ (normal) on log-transformed data & 0.07 & 0.34 & $<0.01$ & 0.61 \\
\hline
\end{tabular}

USCS acronyms are explained in the Appendix n.d. not determined 

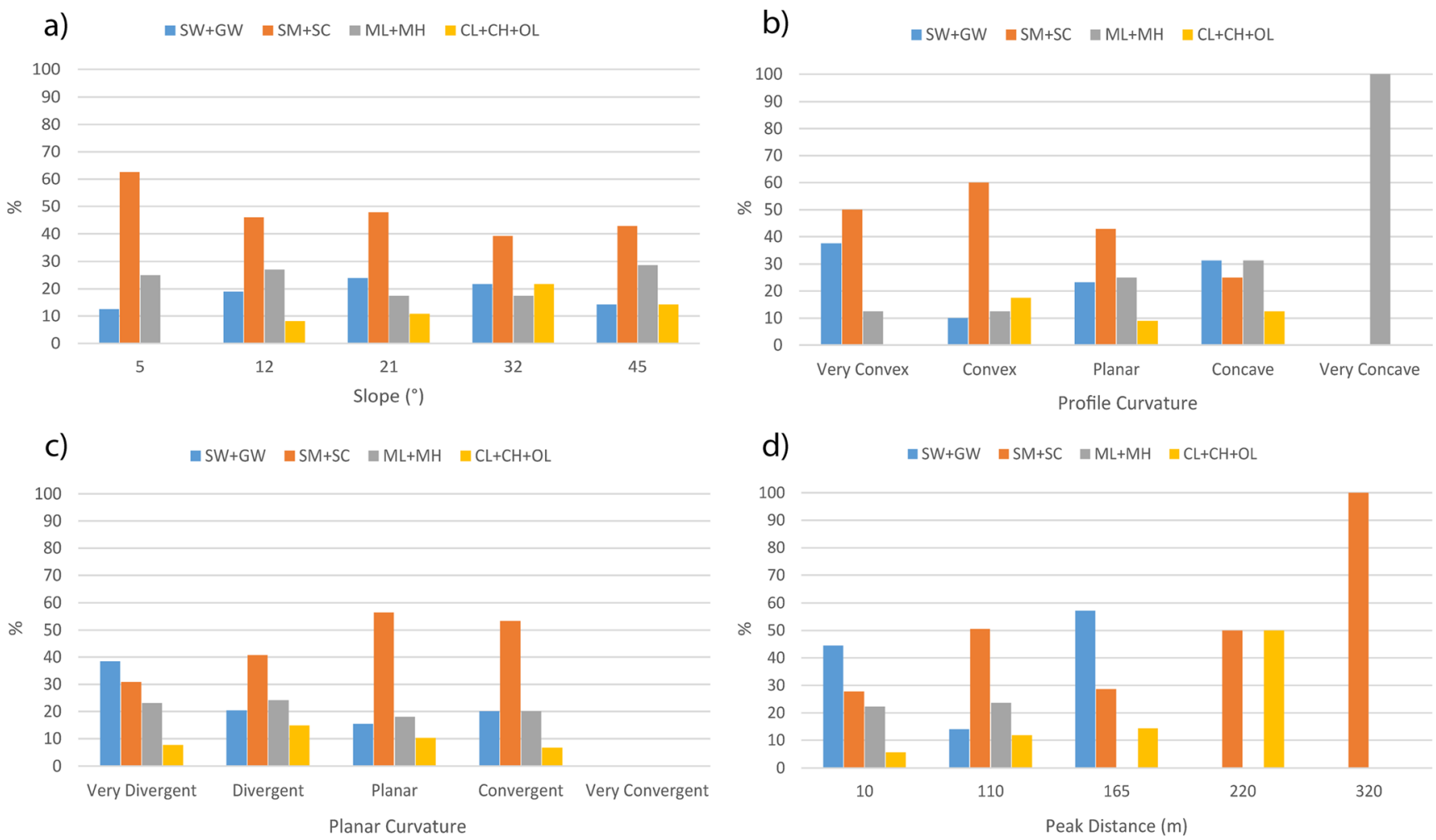

Fig. 10 Occurrence of USCS aggregated soil types with respect to the (a) slope, (b) profile curvature, (c) planar curvature and (d) peak distance in the hillslopes surveyed. USCS acronyms are explained in the Appendix

prevalent while in concave areas the distribution of soil classes is more heterogeneous and all the soil classes are roughly equally represented. This result is mainly due to the fact that in convex areas fine materials are more easily remodeled and transported due to several processes of surface runoff, such as rainwash and sheetwash. The very concave class is constituted by only one sample and for this reason is not statistically representative.

The distribution of soil classes for planar curvature (Fig. 10c) shows that in very divergent areas (crests) coarse granular soils $(\mathrm{SW}+\mathrm{GW})$ prevail over fine granular $(\mathrm{SM}+\mathrm{SC})$ and cohesive ones $(\mathrm{ML}+\mathrm{MH}, \mathrm{CL}+\mathrm{CH}+$ $\mathrm{OL})$. This is in line with the results coming from the profile curvature: in convex and divergent areas, rainwash and sheetwash processes produce residual soils composed of mainly coarse material. In the other classes of planar curvature, silty sands prevail. Nothing can be said about very convergent areas, where no samples have been collected since they usually represent incised channel bottoms or stream thalwegs.

The distribution of soil classes related to the peak distance shows the influence of increasing physical and chemical weathering from low peak distances to high peak distances. In fact, generally it is possible to see that near the peak (up to $\sim 150 \mathrm{~m}$ ) the prevailing soil materials are coarse and silty sands (SW-GW, SM-SC), whilst at greater distances ( 200 m) silty sand and clay prevails.

\section{Conclusions}

In this work, a database of geotechnical (shear strength, unit weight, index properties) and hydrological (saturated hydraulic conductivity) parameters for soil cover in the hillslope deposits in Tuscany (Italy) has been created, with the final aim of improving the way the maps of input parameters are prepared for regional physically-based landslide prediction models. In detail, the specific objectives are: (1) to determine the ranges of variation of the geotechnical and hydrogeological parameters that control shallow landslide triggering mechanisms, and (2) to investigate a way to spatialize the geotechnical and hydrological data according to the information contained in the geological maps and physical factors such as morphology.

The grain size distributions show that the analyzed deposits are generally well sorted and mainly composed of sand and silt, with extremely variable gravel and clay contents. This granulometric composition, however, is not simply dependent on the bedrock typology from which the deposits originated, as the shear strength and hydraulic conductivity are also difficult to predict on the basis of just the geo-lithological maps. In such a framework, direct measurements are the unique possible way to obtain a reliable initial assessment of the values of these properties. The Northern Apennine (the main Tuscany mountain chain) is constituted of extremely complex sedimentary rocks (calcareous, arenaceous and marly flysch) 
sequences, so that geotechnical and hydrological properties of bedrock soil covers are quite difficult to predict without direct measurements. On the other hand, the arrangement of a dense net of survey points and laboratory tests is time- and costexpensive and soil properties are extremely variable and not predictable on the basis of bedrock type. However, we have found that linkages exist between the different USCS soil types with morphometric parameters such as the profile of curvature of the hillslopes. This approach seems promising, as further development and a better inspection of the relationship between the hillslopes curvature and USCS soil type would possibly allow, at least, the ability to predict the distribution of USCS soil types of the deposits in the area of study (i.e., Tuscany) departing from DEMs.

Some parameters, such as the internal friction angle, were found to be well represented by using normal probability distribution functions. Given an appropriate measure of the barycenter and the variance (e.g., arithmetic mean and standard deviation) derived from the analyzed data, these kinds of parameters could be easily reproduced and simulated by deterministic models, as well as interpolated after studying autocorrelation properties by geostatistical tools, thus improving the efficiency with respect to the adoption of constant values and/or equiprobable distributions.

The data presented and discussed in this paper definitely provide a useful experimental set of measures that are expected to (1) improve the performance of numerical models aimed at simulating the stability of hillslopes and assessing the triggering mechanisms for shallow landslides in Tuscany and (2) to provide a way to spatially describe the variation of the geotechnical and hydrological input data for physical numerical models applied to catchment-scale. Indeed, even if in some areas field tests were performed on a large scale (i.e., at a distance of a few dozen meters), the mean distance of test sites and the spatial aggregation criteria we adopted to perform statistical analyses on the dataset make our database suitable not only but mainly for models aimed to provide catchmentscale analyses.

Acknowledgements This work was financially supported by a collaboration between the Department of Earth Sciences (on behalf of the "Centro Interuniversitario di Scienze del Territorio") - University of Florence and the Regional Administration of Tuscany. M. Nocentini, E.B. Masi, F. Raspini and L. Tanteri, as well as master students are warmly thanked for their help in field surveys. We acknowledge the help of E. Pecchioni for XRPD analyses.

\section{Appendix}

\section{USCS acronyms}

GW Well-graded gravel, fine to coarse gravel

GP Poorly graded gravel
SW Well-graded sand, fine to coarse sand

SM Silty sand

SC Clayey sand

ML Silt

MH High plasticity silt

CL Low plasticity clay, lean clay

$\mathrm{CH}$ High plasticity clay

OL Organic silt and clay

\section{Geotechnical and hydrological parameters}
LL (Atterberg) Liquid Limit.
PL (Atterberg) Plastic Limit
PI Plasticity Index
$\mathrm{W}_{\mathrm{n}} \quad$ Natural water content of soils
$\mathrm{yd}_{\mathrm{d}} \quad$ Dry unit weight
y Natural unit weight
$\gamma_{\text {sat }}$ Saturated unit weight
$n \quad$ Bulk porosity
$\varphi^{\prime} \quad$ Effective internal friction angle
c Total cohesion
$\mathrm{k}_{\mathrm{s}} \quad$ Saturated hydraulic conductivity

\section{Statistical acronyms}

clr Centered log ratio

g Geometric mean

Open Access This article is distributed under the terms of the Creative Commons Attribution 4.0 International License (http:// creativecommons.org/licenses/by/4.0/), which permits unrestricted use, distribution, and reproduction in any medium, provided you give appropriate credit to the original author(s) and the source, provide a link to the Creative Commons license, and indicate if changes were made.

\section{References}

Aitchison J (2003) The statistical analysis of compositional data. Blackburn, Caldwell, NJ, USA ISBN 9781930665781

Alvioli M, Baum RL (2016) Parallelization of the TRIGRS model for rainfall-induced landslides using the message passing interface. Environ Model Softw 81:122-135. https://doi.org/10.1016/j. envsoft.2016.04.002

Akbas SO, Kulhawy FH (2010) Characterization and estimation of geotechnical variability in Ankara clay: a case history. Geotech Geol Eng 28:619-631. https://doi.org/10.1007/s10706-010-9320-x

Amoozegar A (1989) Compact constant head permeameter for measuring saturated hydraulic conductivity of the vadose zone. Soil Sci Soc Am J 53:1356-1361. https://doi.org/10.2136/sssaj1989. 03615995005300050009x

Arnone E, Noto LV, Lepore C, Bras RL (2011) Physically- based and distributed approach to analyse rainfall-triggered land- slides at 320 
watershed scale. Geomorphology 133:121-131. https://doi.org/10. 1016/j.geomorph.2011.03.019

ASTM D2217-85 (1998) Standard practice for wet preparation of soil samples for particle-size analysis and determination of soil constants (Withdrawn 2007). ASTM International, West Conshohocken, PA. https://doi.org/10.1520/D2217-85R98

ASTM D422-63e2 (2007) Standard test method for particle-size analysis of soils. ASTM International, West Conshohocken, PA. https://doi. org/10.1520/D0422-63R07E02

ASTM D4318-10e1 (2010) Standard test methods for liquid limit, plastic limit, and plasticity index of soils. ASTM International, West Conshohocken, PA. https://doi.org/10.1520/D4318-10E01

Banchelli A, Fratini F, Germani M, Malesani P, Manganelli Del Fa' C (1997) The sandstones of the fiorentine historic buildings - individuation of the marker and determination of the supply quarries of the rocks used in some Florentine monuments. Sci Technol Cult Herit 6: $13-22$

Baroni G, Facchi A, Gandolfi C, Ortuani B, Horeschi D, van Dam JC (2010) Uncertainty in the determination of soil hydraulic parameters and its influence on the performance of two hydrological models of different complexity. Hydrol Earth Syst Sci 14:251-270. https://doi. org/10.5194/hess-14-251-2010

Baum R., Savage W, Godt J (2002) TRIGRS: a fortran program for transient rainfall infiltration and grid-based regional slope-stability analysis, Open-file Report, US Geol Survey

Baum RL, Godt JW, Savage WZ (2010) Estimating the timing and location of shallow rainfall-induced landslides using a model for transient unsaturated infiltration. J Geophys Res 115:F03013. https:// doi.org/10.1029/2009JF001321

Benda L, Dunne T (1997) Stochastic forcing of sediment supply to channel networks from landsliding and debris flow. Water Resour Res 33:2849-2863. https://doi.org/10.1029/97WR02388

Bicocchi G, D’Ambrosio M, Vannocci P, Nocentini M, Tacconi-Stefanelli C, Masi EB, Carnicelli S, Tofani V, Catani F (2015) Preliminary assessment of the factors controlling the geotechnical and hydrological properties in the hillslope deposits of eastern Tuscany (Central Italy). In: IAMG 2015 Proceedings: 867-874. ISBN 9783000503375

Bicocchi G, D'Ambrosio M, Rossi G, Rosi A, Tacconi-Stefanelli C, Segoni S, Nocentini M, Vannocci P, Tofani V, Casagli N, Catani F (2016) Geotechnical in situ measures to improve landslides forecasting models: a case study in Tuscany (Central Italy). In: Proceedings ISL 2016 congress, 419-424. ISBN 9781138029880

Boccaletti M, Guazzone G (1974) Remnant arcs and marginal basins in the Cenozoic development of the Mediterranean. Nature 252:18-21. https://doi.org/10.1038/252018a0

Bonini M, Sani F (2002) Extension and compression in the northern Apennines (Italy) hinterland: evidence from the late MiocenePliocene Siena-Radicofani Basin and relations with basement structures. Tectonics 21. https://doi.org/10.1029/2001TC900024

Buccianti A (2013) Is compositional data analysis a way to see beyond the illusion? Comput Geosci 50:165-173. https://doi.org/10.1016/j. cageo.2012.06.012

Calcaterra D, Parise M (2010) Weathering as a predisposing factor to slope movements. Geol Soc Lond Spec Publ 23:233. https://doi. org/10.1144/EGSP23.1

Carrara A, Crosta G, Frattini P (2008) Comparing models of debris-flow susceptibility in the alpine environment. Geomorphology 94:353378. https://doi.org/10.1016/j.geomorph.2006.10.033

Casagli N, Dapporto S, Ibsen ML, Tofani V, Vannocci P (2006) Analysis of the landslide triggering mechanism during the storm of 20th-21th November 2000, in northern Tuscany. Landslides 3:13-21. https:// doi.org/10.1007/s10346-005-0007-y

Catani F, Lagomarsino D, Segoni S, Tofani V (2013) Landslide susceptibility estimation by random forests technique: sensitivity and scaling issues. Nat Hazards Earth Syst Sci 13:2815-2831. https:// doi.org/10.5194/nhess-13-2815-2013

Chen HX, Zhang LM (2014) A physically-based distributed cell model for predicting regional rainfall-induced shallow slope failures. Eng Geol 176:79-92. https://doi.org/10.1016/j.enggeo.2014.04.011

Churchman GJ, Lowe DJ (2012) Alteration, formation, and occurrence of minerals in soils. In Handbook of Soil Sciences: Properties and Processes (pp. 1-72). CRC Press

Certini G, Hillier S, McMurray E, Edwards AC (2003) Weathering of sandstone clasts in a forest soil in Tuscany (Italy). Geoderma 116: 357-372. https://doi.org/10.1016/S0016-7061(03)00109-5

Cipriani C (1958) Ricerche sui materiali costituenti le arenarie. I Sulla composizione mineralogica della frazione argillosa di alcune arenarie Macigno. Atti Soc Tosc Scienze Nat 65:86-106

Coli M (1989) Times and modes of uplift of the Alps metamorphic complex northern Apennines, Italy. Atti Ticinensi Sci della Terra 32:4756

Comas-Cufi M, Thió-Henestrosa S (2011) CoDaPack 2.0: a stand-alone, multi-platform compositional software. In: Egozcue JJ, TolosanaDelgado R, Ortego MI, eds. CoDaWork'11: 4th international workshop on compositional data analysis. Sant Feliu de Guíxols; 2011

D’Amato Avanzi G, Giannecchini R, Puccinelli A (2004) The influence of the geological, geomorphological settings on shallow landslides. An example in a temperate climate environment: the June 19, 1996 event in northwestern Tuscany (Italy). Eng Geol 73:215-228. https://doi.org/10.1016/j.enggeo.2004.01.005

Dapporto S, Focardi P, Vannocci P (2000) La parametrizzazione geotecnica di un materiale non saturo mediante prove in sito. Geol Tecn Ambientale 3:5-11

Dietrich WE, McKean J, Bellugi D, Perron T (2007) The prediction of shallow landslide location and size using a multidimensional landslide analysis in a digital terrain model. In: Chen CL, Major JJ (eds) Proceedings of the Fourth International Conference on Debris-Flow Hazards Mitigation: Mechanics, Prediction, and Assessment (DFHM-4); Chengdu, China, September 10-13, 2007. IOS Press, Amsterdam,

Taylor G, Eggleton RA (2001) Regolith geology and geomorphology. Wiley, New York

Elter P, Giglia G, Tongiorgi M, Trevisan L (1975) Tensional and compressional areas in the recent (Tortonian to present) evolution of the northern Apennines. Boll Geofis Teor Applic 42:3-18

Fanelli G, Salciarini D, Tamagnini C (2016) Reliable soil property maps over large areas: a case study in Central Italy. Environ Eng Geosci 22:37-52. https://doi.org/10.2113/gseegeosci.22.1.37

Fredlund DG, Rahardjo H (1993) Soil mechanics for unsaturated soils. Wiley, New York, ISBN:9780470172759. https://doi.org/10.1002/ 9780470172759

Fredlund DG, Morgenstern NR, Widger RA (1978) The shear strength of unsaturated soils. Can Geotech J 15:312-321. https://doi.org/10. 1139/t78-029

Godt JW, Baum RL, Schulz WH, Savage WZ (2008) Modeling rainfall conditions for shallow landsliding in Seattle, Washington. Geol Soc Am Rev Eng Geo XX:137-152. https://doi.org/10.1130/2008. 4020(08)

Goudie AS (2003) Colluvium in a.S. Goodie, ed., p. 173, Encyclopaedia of geomorphology volume 1, A-I. Routledge, New York, N Y ISBN 9780415272988

Goudie AS, Viles H (2008) Weathering processes and forms. In Burt T.P.; Chorley R.J.; Brunsden D.; Cox N.J.; Goudie a.S. quaternary and recent processes and forms. Landforms or the development of Gemorphology. 4. Geological Society, 129-164. ISBN 1862392498

Griffiths DV, Huang JS, Fenton GA (2011) Probabilistic infinite slope analysis. Comput Geotech 38:577-584. https://doi.org/10.1016/j. compgeo.2011.03.006 
Heimsath AM, Dietrich WE, Nishiizumi K, Finkel RC (1997) The soil production function and landscape equilibrium. Nature 388:358 361. https://doi.org/10.1038/41056

Iwashita F, Friedel MJ, Ribeiro GF, Fraser SJ (2012) Intelligent estimation of spatially distributed soil physical properties. Geoderma 170: 1-10. https://doi.org/10.1016/j.geoderma.2011.11.002

Jia N, Mitani Y, Xie M, Djamaluddin I (2012) Shallow landslide hazard assessment using a three-dimensional deterministic model in a mountainous area. Comput Geotech 45:1-10. https://doi.org/10. 1016/j.compgeo.2012.04.007

Jiang SH, Li DQ, Zhang LM, Zhou CB (2013) Slope reliability analysis considering spatially variable shear strength parameters using a nonintrusive stochastic finite element method. Eng Geol 168:120-128. https://doi.org/10.1016/j.enggeo.2013.11.006

Lepore C, Arnone E, Noto LV, Sivandran G, Bras RL (2013) Physically based modeling of rainfall-triggered landslides: a case study in the Luquillo forest, Puerto Rico. Hydrol Earth Syst Sci 17:3371-3387. https://doi.org/10.5194/hess-17-3371-2013

Luttenegger JA, Hallberg BR (1981) Borehole shear test in geotechnical investigations. Am Soc Test Mater Spec Publ 740:566-578. https:// doi.org/10.1520/STP28771S

Martini IP, Vai GB (2001) Anatomy of an Orogen: the Apennines and adjacent mediterranean basins. Kluwer, Dordrecht. https://doi.org/ 10.1007/978-94-015-9829-3

Marra F, Destro E, Nikolopoulos EI, Zoccatelli D, Creutin JD, Guzzetti F, Borga M (2017) Impact of rainfall spatial aggregation on the identification of debris flow occurrence thresholds. Hydrol Earth Syst Sci 21:4525-4532. https://doi.org/10.5194/hess-21-4525-2017

Masi EB (2016) Determination of the organic matter content in some soils of Tuscany and correlation with their geotechnical and mineralogical properties. Dissertation, University of Florence

Mercogliano P, Segoni S, Rossi G, Sikorsky B, Tofani V, Schiano P, Catani F, Casagli N (2013) Brief communication: a prototype forecasting chain for rainfall induced shallow landslides. Nat Hazards Earth Syst Sci 13:771-777. https://doi.org/10.5194/nhess-13-7712013

Montrasio L, Valentino R, Losi GL (2011) Towards a real-time susceptibility assessment of rainfall-induced shallow landslides on a regional scale. Nat Hazards Earth Syst Sci 11:1927-1947. https://doi.org/ 10.5194/nhess-11-1927-2011

Moss AJ, Green P (1975) Sand and silt grains: predetermination of their formation and properties by microfractures in quartz. Aust $\mathrm{J}$ Earth Sci 22:485-495. https://doi.org/10.1080/00167617508728913

Nikolopoulos EI, Crema S, Marchi L, Marra F, Guzzetti F, Borga M (2014) Impact of uncertainty in rainfall estimation on the identification of rainfall thresholds for debris flow occurrence. Geomorphology 221:286-297. https://doi.org/10.1016/j.geomorph. 2014.06.015

Oreskes N, Shrader-Frechette K, Belitz K (1994) Verification, validation, and confirmation of numerical models in the earth sciences. Science 263:641-646. https://doi.org/10.1126/science.263.5147.641

Pack R, Tarboton D, Goodwin C (2001) assessing terrain stability in a GIS using SINMAP, in: 15th annual GIS conference, GIS, 2001

Park HJ, Lee JH, Woo I (2013) Assessment of rainfall-induced shallow landslide susceptibility using a GIS-based probabilistic approach. Eng Geol 161:1-15. https://doi.org/10.1016/j.enggeo.2013.04.011

Pazzi V, Tanteri L, Bicocchi G, D’Ambrosio M, Caselli A, Fanti R (2016) $\mathrm{H} / \mathrm{V}$ measurements as an effective tool for the reliable detection of landslide slip surfaces: case studies of Castagnola (La Spezia, Italy) and Roccalbegna (Grosseto, Italy). Phys Chem Earth, Parts A/B/C. https://doi.org/10.1016/j.pce.2016.10.014

Peres DJ, Cancelliere A (2014) Derivation and evaluation of landslidetriggering thresholds by a Monte Carlo approach. Hydrol Earth Syst Sci 18:4913-4931. https://doi.org/10.5194/hess-18-4913-2014

Peres DJ, Cancelliere A, Greco R, Bogaard TA (2018) Influence of uncertain identification of triggering rainfall on the assessment of landslide early warning thresholds. Nat Hazards Earth Syst Sci 18: 633-646. https://doi.org/10.5194/nhess-18-633-2018

Philip JR (1985) Approximate analysis of the borehole permeameter in unsaturated soil. Water Resour Res 21:1025-1033. https://doi.org/ 10.1029/WR021i007p01025

Phoon KK, Kulhawy FH (1999) Characterization of geotechnical variability. Can Geotech J 36:612-624. https://doi.org/10.1139/t99-038

Raia S, Alvioli M, Rossi M, Baum RL, Godt JW, Guzzetti F (2014) Improving predictive power of physically based rainfall-induced shallow landslide models: a probabilistic approach. Geosci Model Dev 7:495-514. https://doi.org/10.5194/gmd-7-495-2014

Rawls WJ, Brakensiek DL, Saxton KE (1982) Estimation of soil water properties. Trans ASAE 25:1316-1320. https://doi.org/10.13031/ 2013.33720

Reid ME, Christian SB, Brien DL, Henderson ST (2015) Scoops3Dsoftware to analyze 3D slope stability throughout a digital landscape: U.S. Geological Survey Techniques and Methods, book 14, chap A1, 218 p. https://doi.org/10.3133/tm14A1

Ren D, Fu R, Leslie LM, Dickinson R, Xin X (2010) A storm-triggered landslide monitoring and prediction system: formulation and case study. Earth Interact 14:1-24. https://doi.org/10.1175/2010EI337.1

Ren D, Leslie L, Lynch M (2014) Trends in storm-triggered landslides over Southern California. J Appl Meteor Climatol 53:217-233. https://doi.org/10.1175/JAMC-D-12-0253.1

Rinaldi M, Casagli N (1999) Stability of streambanks formed in partially saturated soils and effects of negative pore water pressures: the Sieve River (Italy). Geomorphology 26:253-277. https://doi.org/10.1016/ S0169-555X(98)00069-5

Rosi A, Tofani V, Tanteri L, Tacconi Stefanelli C, Agostini A, Catani F, Casagli N (2017) The new landslide inventory of Tuscany (Italy) updated with PS-InSAR: geomorphological features and landslide distribution. Landslides 15:5-19. https://doi.org/10.1007/s10346017-0861-4

Rossi G, Catani F, Leoni L, Segoni S, Tofani V (2013) HIRESSS: a physically based slope stability simulator for HPC applications. Nat Hazards Earth Syst Sci 13:151-166. https://doi.org/10.5194/ nhess-13-151-2013

Rosso R, Rulli MC, Vannucchi G (2006) A physically based model for the hydrologic control on shallow landsliding. Water Resour Res 42: W06410. https://doi.org/10.1029/2005WR004369

Salciarini D, Tamagnini C, Conversini P, Rapinesi S (2012) Spatially distributed rainfall thresholds for the initiation of shallow landslides. Nat Hazards 61:229-245. https://doi.org/10.1007/s11069-0119739-2

Salciarini D, Fanelli G, Tamagnini C (2017) A probabilistic model for rainfall-induced shallow landslide prediction at the regional scale. Landslides 14:1731-1746. https://doi.org/10.1007/s10346-0170812-0

Salvatici T, Tofani V, Rossi G, D'Ambrosio M, Tacconi-Stefanelli C, Masi EB, Rosi A, Pazzi V, Vannocci P, Petrolo M, Catani F, Ratto S, Stevenin H, Casagli N (2018) Regional physically based landslide early warning modelling: soil parameterisation and validation of the results. Nat Hazards Earth Syst Sci 18:1919-1935. https://doi.org/ 10.5194/nhess-18-1919-2018

Segoni S, Leoni L, Benedetti AI, Catani F, Righini G, Falorni G, Gabellani S, Rudari R, Silvestro F, Rebora N (2009) Towards a definition of a real-time forecasting network for rainfall induced shallow landslides. Nat Hazards Earth Syst Sci 9:2119-2133. https://doi.org/10.5194/nhess-9-2119-2009

Segoni S, Rossi G, Catani F (2012) Improving basin scale shallow landslide modelling using reliable soil thickness maps. Nat Hazards 61: 85-101. https://doi.org/10.1007/s11069-011-9770-3

Simoni S, Zanotti F, Bertoldi G, Rigon R (2008) Modelling the probability of occurrence of shallow landslides and channelized debris flows using geotop-fs. Hydrol Process 22:532-545. https://doi.org/10. 1002/hyp.6886 
Shapiro SM, Wilk MB (1965) An analysis of variance test for normality (complete samples). Biometrika 52:591-611. https://doi.org/10. 2307/2333709

Thomas CW, Aitchison J (2005) Compositional data analysis of geological variability and process: a case study. Math Geol 37:753-772. https://doi.org/10.1007/s11004-005-7378-4

Tao J, Barros AP (2014) Coupled prediction of flood response and debris flow initiation during warm- and cold-season events in the southern Appalachians USA. Hydrol Earth Syst Sci 18:367-388. https://doi. org/10.5194/hess-18-367-2014

Tofani V, Dapporto S, Vannocci P, Casagli N (2006) Infiltration, seepage and slope instability mechanisms during the 20-21 November 2000 rainstorm in Tuscany, Central Italy. Nat Hazards Earth Syst Sci 6: 1025-1033. https://doi.org/10.5194/nhess-6-1025-2006

Tofani V, Bicocchi G, Rossi G, Segoni S, D’Ambrosio M, Casagli N, Catani F (2017) Soil characterization for shallow landslides modeling: a case study in the northern Apennines (Central Italy). Landslides 14:755-770. https://doi.org/10.1007/s10346-017-0809-8
Tucker GE, Catani F, Rinaldo A, Bras RL (2001) Statistical analysis of drainage density from digital terrain data. Geomorphology 36:187202. https://doi.org/10.1016/S0169-555X(00)00056-8

von Eynatten H (2004) Statistical modelling of compositional trends in sediments. Sediment Geol 171:79-89. https://doi.org/10.1016/j. sedgeo.2004.05.011

Wagner AA (1957) The use of the Unified Soil Classification System by the Bureau of Reclamation. Proc 4th Intern Conf Soil Mech Found Eng London I:125

Wright JS, Smith BJ, Whalley WB (1998) Mechanisms of loess-sized quartz silt production and their relative effectiveness: laboratory simulations. Geomorphology 45:15-34. https://doi.org/10.1016/ S0169-555X(97)00084-6

Zizioli D, Meisina C, Valentino R, Montrasio L (2013) Comparison between different approaches to modeling shallow landslide susceptibility: a case history in Oltrepo Pavese, northern Italy. Nat Hazards Earth Syst Sci 13:559-573. https://doi.org/10.5194/nhess-13-5592013 